\title{
OVERLAPPING DUTY OF PARENTS IN DISTANCE LEARNING DURING PANDEMIC AND ITS IMPACT ON CHILD'S PSYCHE AT TK AL-AMANAH CAMPOR BARAT AMBUNTEN SUMENEP
}

\author{
Barratun Naqiyah \\ Institut Ilmu KeIslaman Annuqayah (INSTIKA) Guluk-Guluk \\ bunda8aesar@gmail.com \\ Handoko Ja'far \\ STAI Ma'had Aly Al-Hikam Malang \\ hokohan@yahoo.co.id
}

\begin{abstract}
This article aims to determine the impact of overlapping parental duties during the pandemic on the psychological condition of children in Distance Learning, based on the results of interviews and observations of students and their guardians at Al-Amanah Campor Barat Kindergarten, Ambunten Sumenep. This article identifies the overlapping duties of parents, namely studying children's school assignments, motivating the children to learn, finding a stable internet network, and providing the monthly internet quotas. Furthermore, the overlapping of parental duties during distance learning has a negative impact on the child's psyche. The indicator is that children feel bored and even cry, because often parents are impatient and yell at them during the implementation of distance learning.
\end{abstract}

Keywords: Parents' Duties, Distance Learning, Child's Psyche.

\section{A. Introduction}

Up to now, the Covid-19 outbreak has not ended, since WHO announced on March 11, 2020, that Covid-19 has become a pandemic (Qun Li et al., 2020). As the days go by, the spread of this virus is increasingly widespread, massive, and unstoppable throughout the world, included Indonesia. To break the chain of transmission, almost all countries, 
including Indonesia, have implemented policies on physical distancing and social distancing.

The Covid-19 pandemic has changed the world order in various fields, such as health, economy, socio-culture, and education. In the field of education, the Indonesian government has established a learning from home policy based on the Circular of the Minister of Education and Culture Number 36962/MPK.A/HK/2020 which states that learning must be done online so that Covid-19 can be prevented from spreading (Karnawati \& Mardiharto, 2020).

Online learning is learning that reduces time and distance with the help of an internet-based digital platform that is able to support learning to be carried out without any physical interaction between educators and students (Rizki Saga Putra, 2020). Methods and media used for implementing the learning from home are carried out through Distance Learning with two approaches, namely online learning and offline one (Kementerian Pendidikan dan Kebudayaan, 2020).

The online learning set by the government is aimed at all levels of education, from kindergarten to university. The implication is that the educational role that was originally carried out by the educational institution is replaced by the family so that the house becomes the center of educational activities. This phenomenon has a double impact, on the one hand, it has a positive impact to restore the function of the house as a center for educational activities; and on the other hand, has a negative impact, parents are "forced" to take on new additional tasks as substitute teachers or collaborators with teachers during distance learning. This is a big and serious challenge for parents (Haerudin et al., 2020), because not all parents have adequate pedagogic competence. For example, in distance learning, parents are required to be active and creative, so that children can learn effectively learn and the learning is fun.

Effective and enjoyable learning can be achieved through the play method. Therefore, playing is an approach to learning at the level of early childhood education. Through activities engaged in for enjoyment and recreation, children are invited to explore, find and use objects in the surrounding environment, so that learning is more meaningful for children 
because children can build understanding based on their experiences while playing (Departemen Pendidikan Nasional, 2007).

The application of the playing method is compatible with the children's characteristics. In Islamic education, the prophet emphasized the importance of playing with children. He said: "Whoever has a child, let him play with him". In another Hadith, he said: "Whoever makes his child happy, then (the reward) is like freeing a slave. Whoever jokes to please his child, then (the reward) is like crying out of fear of Allah" (Musbikin, 2010).

In fact, parents who accompany their children in distance learning, are often unable to apply fun learning through play activities, thus burdening the psychological condition of children. They feel bored and even afraid to learn with their parents. In the author's opinion, one of the factors that cause this is the overlapping of parents' duties during the implementation of distance learning. Overlapping this task causes stress for parents, so they cannot provide an effective and fun learning atmosphere when accompanying their children during distance learning.

Other factors that become obstacles for parents in implementing distance learning are lack of understanding of the material being taught, difficulty in growing children's interest in learning, difficulty to operate the gadgets, not having enough time to accompany children, not being patient enough, and having problem of quality network or internet connection (Anita Wardani, 2021).

When parents experience problems when accompanying their children in distance learning, it also has an impact on the child's psyche. Therefore, this article aims to identify the overlapping duties of parents in implementing distance learning; review the impact on the child's psyche, and propose alternative solutions to overcome these problems.

\section{B. Overlapping Parents' Duties in the Implementation of Distance Learning at Al-Amanah Kindergarten}

The implementation of distance learning through online ways requires a variety of new tasks for parents, for the sake of the child's success. The following are the results of the identification of researchers related to 
the duties of parents when accompanying children in distance learning at home during the Covid-19 pandemic which are classified as overlapping.

\section{Studying the School Task Materials}

When accompanying children during distance learning, many parents must first learn the material for their children's school assignments. This is reflected in the following interview results:

"Since the implementation of Distance Learning, I have to study again. Especially when the teacher asks my child to read daily prayers and short letters, not all of which I memorize" (Rofita, 2021).

"Once the teacher asked to make a video of a child reading the five precepts of Pancasila. At that time, it happened that my son did not memorize it. Then my son asked me, and I myself was confused what to do because I didn't really memorize the five precepts" (Anisah, 2021).

"I have to learn the butterfly metamorphosis due to at that time my child was asked by his teacher to explain the butterfly metamorphosis process" (Cicik, 2021).

The data above shows that the implementation of distance learning forces the parents to carry out additional tasks, such as studying the material for school assignments given to their children, especially related to cognitive aspects; memorizing and understanding the material for children's school assignments.

Distance learning assistance does not work effectively if parents do not know or understand the material for their child's school assignments. Therefore, parents must master the learning materials provided by the teacher to their children, so that distance learning assistance at home runs successfully (Mega Ria Agustina, 2021). In other words, parents' knowledge and understanding of their child's school assignment material play an important role in improving the quality of distance learning with their children (Irhamna, 2016).

\section{Motivating the Children's Learning}

Another problem faced by parents in assisting the distance learning at home is the lack of children's motivation to learn. Often children do not 
want to study during distance learning for various reasons, as shown in the following interview results:

"When distance learning is conducted, my child is hard to be invited to learn and do assignments from the teacher. This is due to every day we see neighboring children playing in the yard because we happen to live in densely populated housing" (Unsiyah, 2021).

"Often when it's time to learn, my children always say they want to learn at school. He said that he prefers to learn at school than at home" (Sri, 2021).

"I always promise my children a reward if they want to learn and want to complete assignments from their teachers in distance learning; if not, my son is often to say that he's tired" (Husnul, 2021).

The problem of the lack of children's learning motivation experienced by some of the parents is in line with the psychological characteristics of early childhood which tend to have short attention spans, except for things that are intrinsically fun, such as playing. The proof is that in early childhood is still very difficult to sit and pay attention to something for a long period of time, such as when taking distance learning (Masitoh, dkk., 2011). Therefore, parents need to apply various methods and media of instruction that are suitable for children's learning styles, so that children are motivated to learn during distance learning (Suyadi, 2010). The implication is that parents have an additional task during distance learning mentoring, which is to actively motivate children's learning in various ways so that children focus on learning.

\section{Searching for Internet Network}

Implementation of distance learning through online learning requires a stable internet network. The problem is, not all areas have a stable internet network connection. For children whose house is far from the reach of the internet network, it requires their parents to find a certain place or location outside the home where the internet network is stable. This was experienced by the following parents: 
"In my house, the signal is weak and even hard to reach, so every time there is an assignment from the teacher, I also have to look for signals outside the house, in several places, in order to be able to open the task" (Imaniyah, 2021).

"In learning the sports or gymnastics, the teacher often asks to record my child exercises to be submitted. Yet, there always the problem of a network at home that is usually weak so that I take a photo instead." (Masriyana, 2021).

The data above shows that parents engaged in additional tasks during distance learning, looking for signals in several locations in hope that the internet connection runs stable, in order to do their children's school assignments. Moreover, parents are required to have additional tasks in the form of taking photos or videos of children's learning activities, then submit to their child's teacher, as proof of the child's presence and activity.

\section{Providing the Internet Quota}

Internet quota is a primary requirement in the implementation of distance learning. The problem is that parents have to pay a lot of money to buy an internet quota for the benefit of their child's distance learning. For parents whose economic conditions are middle to lower, purchasing an internet quota becomes an additional charge. That is, parents must find special funds allocated for purchasing the internet quota. This problem was also conveyed by the following parents:

"I have to provide more internet quotas than before. If previously 3 GB was enough for a month. Since the implementation of distance learning, I have to spend more than 3 GB, sometimes 5 GB to 8 GB for a month" (Nia, 2021).

"During this online learning, I spend wastefully for the internet quota as my son puts forward a condition. He agrees to learn on the condition that after online learning, he is allowed to access Tik-Tok and Youtube applications" (Aan, 2021). 
The data above shows an increase in the cost of purchasing internet quota during distance learning. Especially if the child uses the internet quota for entertainment, such as playing TikTok and watching Youtube.

Although Nadiem Makarim as the Ministry of Education and Culture of the Republic of Indonesia has released a policy of providing subsidies for purchasing internet quotas; it turns out that the majority of guardians at $\mathrm{Al}$ Amanah Kindergarten admit that they have never received such assistance. As a result, the parents who have to buy internet quota for the benefit of their child's distance learning; so that parents have an additional burden to find special funds to purchase internet quota.

\section{The Impact of the Overlapping of Parents' Duties in the Implementation of distance learning on Children's Psychic Conditions}

Based on the results of interviews with 12 Al-Amanah Kindergarten students who underwent online learning; all admitted that they were not happy with distance learning at home. This is based on several complaints submitted by 12 Al-Amanah Kindergarten students regarding the implementation of distance learning:

First, the feeling of fear. Al-Amanah Kindergarten students admitted to feeling afraid when studying with their parents during online PJJ. The reason is that the majority of parents are not patient enough when accompanying their children during distance learning. The impatience of parents is triggered by the overlapping of tasks that must be done by parents in the implementation of distance learning so that parents admit to experiencing stress, then vent it in the form of anger towards their children during the implementation of distance learning.

Second, feelings of anxiety. Some of the Al-Amanah Kindergarten students said they were worried, because of the many assignments given by the teacher in the implementation of distance learning. The number of school assignments during distance learning, not only distresses children as students but also burdens parents as companions during the implementation of distance learning. The majority of parents admitted that 
they were forced to do the school assignment as there were too many and the children were unable to do it themselves. In fact, parents also often do not know or do not understand the assignment material given by the teacher to their children.

Third, feeling bored and saturated. Based on the results of observations on the implementation of online learning conducted by children with their parents, the main factor that makes children bored in implementing distance learning is the learning method applied by parents is serious and monotonous, so learning is not fun at all for children.

Fourth, easy to stress. In normal learning at school, Al-Amanah Kindergarten students are given the freedom to learn as they wish. Even if they don't want to do their homework, Al-Amanah Kindergarten students are not forced. Just asked to repeat again the next day. Unlike the case with the implementation of online learning at home. Parents often force their children to study and do the assignments given by the teacher. If children do not want to learn and do their assignments, parents often scold, yell, and even pinch their children. This is what makes children easily stressed, and even crying.

\section{Alternative Solutions to the Problem of Overlapping Parents' Duties in the Implementation of Distance Learning}

\section{Parents Collaborate with Teachers}

The success of early childhood education is determined by the harmonious cooperation between parents, teachers, and the community which is called by Ki Hajar Dewantara as the Three Education Centers (Suyadi \& Maulidya Ulfah, 2013).

In line with that, in the Parenting Webinar 1 held by the Nahdlatul Ulama Family Benefit Institution-Nahdlatul Ulama Branch Manager (LKKNU-PCNU) Sumenep on February 21, 2021, with the theme "Children's Education in a Pandemic Period", Siti Qudsiati Utami as the key speaker asserted that teachers should not sit idly by and consider their work done when they have handed over their children's school task to their parents at home. Teachers must know, listen, and participate in solving the 
difficulties experienced by children and parents during distance learning (Utami, 2021 ).

In practice, both parents and teachers are required to be proactive in establishing collaborations, in order to improve the quality of children's learning while taking online classes at home.

\section{Understanding the Child Psychology and his Learning Style}

To overcome the psychological problems of children when taking distance learning or online class at home, such as fear, anxiety, boredom, and stress, people need to know learning methods that are in accordance with the psychology and learning styles of their respective children.

For example, theoretically, learning at the kindergarten level generally applies a fun learning approach or is more popularly known as edutainment (Suyadi, 2010). In other words, edutainment is an effort made by educators (teachers and parents) to create a pleasant learning atmosphere by emphasizing the emergence of feelings of joy and positive emotions in children. Examples of edutainment are learning while playing, coloring or singing.

The importance of edutainment in early childhood learning is reinforced by research results that show that mothers who teach their children calmly and seriously, which emphasizes the learning aspect rather than playing, make children undergo the learning process calmly and seriously. On the other hand, mothers are more relaxed and tend to express joy with sounds, movements, and even noise; Instead, it shows better learning outcomes than mothers who teach their children calmly and seriously (Sunartyo, 2006).

To be more optimal, parents need to recognize their child's learning style, because every child has their own learning style. In general, children's learning styles include visual, auditory, and kinesthetic (Suyadi, 2010). In practice, if the child has a visual style, then parents can teach their child by reading books or watching videos. If the child has an auditory style, then parents can teach their child the lecture or storytelling method. If the child has a kinesthetic style, then parents can teach their child while allowing the child to move freely, without requiring him to sit still. 


\section{Empathy and Good Communication}

In the implementation of distance learning, there are still a number of parents who have not been able to treat their children well. For example, likes to scold and force children to learn and do their school task. According to Siti Qudsiati Utami, the key to overcoming the above problems is empathy and communication (Utami, 2021 ).

To increase empathy for children, parents should realize that distance learning is a positive moment to increase the harmony of parent-child relationships. If parents have this view, then parents can enjoy and take advantage of the distance learning moment to show their affection for their children.

Parental love is an important factor for all children's lives in the future (Sunartyo, 2006). Therefore, parents need to present attitudes and actions that reflect affection for children during distance learning, such as teaching children casually while playing; and avoid attitudes and actions that do not reflect affection for children, such as scolding and forcing children during distance learning.

On the other hand, parents must communicate well with their children. In practice, parents can build an agreement with their children regarding the rules during the implementation of distance learning. For example, children may not play during online learning and are allowed to play after distance learning (Utami, 2021 ).

\section{Proactive in Fulfilling Internet Quota Needs}

To meet the need for internet quotas, parents need to be proactive in seeking information related to internet quota assistance provided by the Ministry of Education and Culture (Kemendikbud). For example, actively accessing the official website of the Ministry of Education and Culture regarding internet data quota assistance on the https://kuotalearning.kemdikbud.go.id/ page. Parents are also proactive in finding out the conditions for getting it. For example, for Kindergarten, Elementary, and Secondary Education students, the requirements for obtaining internet data quota assistance from the Ministry of Education and Culture are a) Registered in the Dapodik application; b) Have an active mobile number on behalf of the student/parent/family member/guardian (Azanella, 2021) 


\section{E. Conclusion}

The overlapping of parental tasks in the implementation of distance learning-online learning at Al-Amanah Kindergarten turned out to have a negative impact on the child's psychological condition which has the potential to stretch the affectionate relationship between parents and their children. As an alternative solution, parents are required to be proactive to improve this situation, through intensive collaboration with teachers and other parties who are competent in educating early childhood; so that the implementation of online PJJ can be effective and fun so that it has implications for increasing the motivation and learning achievement of children in Al-Amanah Kindergarten.

\section{BIBLIOGRAPHY}

Aan, I. (2021, March 17). Overlapping Tugas Orangtua dalam PJJ. (B. Naqiyah, Interviewer)

Anisah, I. (2021, March 15). Overlapping Tugas Orangtua dalam PJJ. (B. Naqiyah, Interviewer)

Anita Wardani, Y. A. (2021). Analisis Kendala Orang Tua dalam Mendampingi Anak Belajar di Rumah Pada Masa Pandemi Covid19. Jurnal Obsesi, 5(1), 772-782.

Azanella, L. A. (2021, April 13). 7 Hal yang Perlu Diketahui soal Kuota Internet Gratis Kemdikbud. Retrieved from https://www.kompas.com/tren/read/2021/04/13/110400965/7-halyang-perlu-diketahui-soal-kuota-internet-gratiskemdikbud?page=all.

Cicik, I. (2021, March 15). Overlapping Tugas Orangtua dalam PJJ. (B. Naqiyah, Interviewer)

Departemen Pendidikan Nasional. (2007). Konsep Pengembangan Kurikulum Anak Usia Dini. Jakarta: Pusat Kurikulum Badan Penelitian dan Pengembangan Departemen Pendidikan Nasional. 
Haerudin et al. (2020, May 28). Peran Orangtua dalam Membimbing Anak Selama Pembelajaran di Rumah sebagai Upaya Memutus Covid-19. Retrieved from https://www.researchgate.net/publication/341708783_PERAN_ORA NG_TUA_DALAM_MEMBIMBING_ANAK_SELAMA_PEMBELAJ ARAN_DI_RUMAH_SEBAGAI_UPAYA_MEMUTUS_COVID19/link/5ecfc59f92851c9c5e65afd4/download.

Husnul, I. (2021, March 15). Overlapping Tugas Orangtua dalam PJJ. (B. Naqiyah, Interviewer)

Imaniyah, I. (2021, March 17). Overlapping Tugas Orangtua dalam PJJ. (B. Naqiyah, Interviewer)

Irhamna. (2016). Analisis tentang Kendala-Kendala yang Dihadapi Orang Tua dalam Pembinaan Akhlak dan Kedisiplinan Belajar Siswa Madrasah Darussalam Kota Bengkulu. al-Bahtsu, 1(1), 56-65.

Karnawati \& Mardiharto. (2020). Sekolah Minggu Masa Pandemi Covid 19: Kendala, Solusi, Proyeksi. Didaché, 1(1), 13-24.

Kementerian Pendidikan dan Kebudayaan. (2020, May 29). Kemendikbud Terbitkan Pedoman Penyelenggaraan Belajar dari Rumah. Retrieved from https://www.kemdikbud.go.id/main/blog/2020/05/kemendikbudterbitkan-pedoman-penyelenggaraan-belajar-dari-rumah.

Masitoh, dkk. (2011). Strategi Pembelajaran TK. Jakarta: Universitas Terbuka. Masriyana, I. (2021, March 17). Overlapping Tugas Orangtua dalam PJJ. (B. Naqiyah, Interviewer)

Mega Ria Agustina, N. D. (2021). Keterlibatan Orang Tua dalam Mendampingi Anak Usia Dini Belajar dari Rumah di Masa Pandemi Covid-19. Jurnal Obsesi, 5(2), 214-224.

Musbikin, I. (2010). Buku Pintar PAUD: Tuntunan Lengkap dan Praktis Para Guru. Yogjakarta: Laksana.

Nia, I. (2021, March 17). Overlapping Tugas Orangtua dalam PJJ. (B. Naqiyah, Interviewer) 
Qun Li et al. (2020). Early Transmission Dynamics in Wuhan, China, of Novel Coronavirus-Infected Pneumonia. The New England Journal of Medicine, 382 (13), 1199-1207.

Rizki Saga Putra, I. (2020). Media Komunikasi Digital, Efektif Namun Tidak Efisien: Studi Media Richness Theory dalam Pembelajaran Jarak Jauh Berbasis Teknologi di Masa Pandemi. Global Komunika, 1(2), 113.

Rofita, I. (2021, March 15). Overlapping Tugas Orangtua dalam PJJ. (B. Naqiyah, Interviewer)

Sri, I. (2021, March 15). Overlapping Tugas Orangtua dalam PJJ. (B. Naqiyah, Interviewer)

Sunartyo, N. (2006). Membentuk Kecerdasan Anak Sejak Dini. Yogjakarta: Think.

Suyadi \& Maulidya Ulfah. (2013). Konsep Dasar PAUD. Bandung: Remaja Rosdakarya.

Suyadi. (2010). Psikologi Belajar PAUD. Yogyakarta: Pedagogi.

Unsiyah, I. (2021, March 15). Overlapping Tugas Orangtua dalam PJJ. (B. Naqiyah, Interviewer)

Utami, S. Q. (Performer). (2021, February 21). Webinar Parenting 1: Pendidikan Anak di Masa Pandemi. Sumenep, Jawa Timur. 